\title{
MANNITOL VS. METHACHOLINE IN THE EVALUATION OF AIRWAY RESPONSIVENESS IN BAKERS' ASTHMA
}

\author{
EWA NOWAKOWSKA-ŚWIRTA, MARTA WISZNIEWSKA, AGNIESZKA LIPIŃSKA-OJRZANOWSKA, \\ and JOLANTA WALUSIAK-SKORUPA \\ Nofer Institute of Occupational Medicine, Łódź, Poland \\ Department of Occupational Diseases and Environmental Health
}

\begin{abstract}
Objectives: Various indirect or direct airway challenge tests are used to measure nonspecific bronchial hyper-responsiveness (NSBHR). The evaluation of NSBHR in diagnosing occupational asthma (OA) is performed, e.g., to monitor the specific inhalation challenge test (SICT). The aim of this study was to preliminarily compare the results of methacholine and mannitol inhalation challenge tests in SICT monitoring in bakers with work-related airway symptoms. Material and Methods: Four bakery workers with a suspicion of OA underwent single-blind placebo-controlled SICTs involving workplace allergens, accompanied by the evaluation of NSBHR with mannitol and methacholine, both before and after SICTs. Clinical examinations, spirometry tests, skin prick tests (SPTs) to common aeroallergens and occupational allergens, as well as tests to determine serum specific IgE antibodies to occupational aeroallergens were also performed. Results: Positive SPTs results to occupational aeroallergens were found in all bakery workers, and specific IgE antibodies to flour were detected in 2 subjects. Three patients displayed positive SICT reactions. In all of these 3 patients, airway responsiveness to methacholine increased significantly. In 2 patients, airway reaction to mannitol was significant, whereas in 1 subject there was no increase in NSBHR after mannitol inhalation. The patient with a negative SICT result did not reveal any changes in NSBHR before and after the test, either to methacholine or mannitol. Conclusions: The data obtained by the authors show that there is no clear correlation between the methacholine and mannitol inhalation challenge tests in SICT monitoring. Preliminary results indicate the need for further investigations to evaluate the usefulness of the mannitol challenge test in the diagnostics of OA. Int J Occup Med Environ Health. 2020;33(2):235-9
\end{abstract}

Key words:

mannitol, methacholine, nonspecific bronchial hyper-responsiveness, occupational asthma, specific inhalation challenge test, bakery workers

\section{INTRODUCTION}

Various indirect or direct airway challenge tests are used to measure nonspecific bronchial hyper-responsiveness (NSBHR). The evaluation of NSBHR at baseline and after a specific inhalation challenge test (SICT) for diagnosing occupational asthma $(\mathrm{OA})$ is needed [1]. For example, a methacholine challenge test is used for confirming occupational asthma, but while its sensitivity in diagnosing clinically significant asthma is excellent, the specificity is poor [2]. To date, few studies have evaluated the mannitol challenge test in occupational settings. The recently published data demonstrated that the mannitol challenge test has high specificity but low sensitivity to detect symptomatic subjects in the workplace [3].

The aim of this study was to preliminarily compare the results of methacholine and mannitol inhalation challenge tests in SICT monitoring in bakers with work-related airway symptoms.

Received: March 22, 2019. Accepted: December 9, 2019.

Corresponding author: Ewa Nowakowska-Świrta, Nofer Institute of Occupational Medicine, Department of Occupational Diseases and Environmental Health, św. Teresy 8, 91-348 Łódź, Poland (e-mail: Ewa.Nowakowska-Swirta@imp.lodz.pl). 


\section{MATERIAL AND METHODS}

The study group consisted of 4 bakery workers with a suspicion of OA, who were admitted to the Department of Occupational Diseases.

Physical examinations and routine laboratory tests were performed on admission to the hospital. Sensitization to common and occupational allergens was tested using SPTs (Allergopharma, Germany, and Stallergenes, France); the levels of serum allergen-specific IgE antibodies (asIgE) to workplace allergens were also evaluated (ImmunoCap System, Phadia, Sweden). All spirometry measurements were carried out using the Jaeger Master Scope Spirometer (VIASYS HealthCare, Germany). The placebo-controlled SICTs with wheat, barley, rye and oat flour were conducted using a standardized protocol in a special challenge room. The SICT response was evaluated according to a previously described protocol and international recommendations [1,4].

Bronchial provocation tests with methacholine and mannitol were performed before and after SICTs according to a standardized methodology. The provocation concentration $\left(\mathrm{PC}_{20}\right)$ of methacholine to cause a $20 \%$ decrease in the forced expiratory volume in $1 \mathrm{~s}\left(\mathrm{FEV}_{1}\right)$ was measured $48 \mathrm{~h}$ before and after SICTs. The mannitol challenge test was performed using the Aridol test kit (Pharmaxis Ltd., New South Wales, Australia) containing dry powdered mannitol. The provocation dose $\left(\mathrm{PD}_{15}\right)$ of mannitol to cause a $15 \%$ decrease in $\mathrm{FEV}_{1}$, was measured $24 \mathrm{~h}$ before and after SICTs. A positive result of the bronchial hyper-responsiveness test was defined as a $15 \%$ decrease in $\mathrm{FEV}_{1}$ to $\leq 635 \mathrm{mg}$ [5].

The exclusion criterion for the study was the continuous use of antihistamines, oral corticosteroids and antidepressants.

\section{Ethics}

The Regional Bioethical Committee approved the study protocol. The involved patients were informed about the research process in an oral and written manner, and the participation in the study required their written informed consent.

\section{RESULTS}

The baseline characteristics and presenting symptoms of the patients are summarized in Table 1. The detailed results of SPTs to common occupational allergens, asIgE to occupational allergens, and the results of methacholine concentrations and mannitol doses before and after SICTs are presented in Table 2.

The SICT with occupational allergens was positive in 3 bakers. In all of the patients with positive SICT results, airway responsiveness to methacholine increased significantly. In 2 patients, airway reaction to mannitol was significant, whereas in 1 subject with a positive SICT result, no increase in NSBHR was observed after mannitol inhalation. The patient with a negative SICT result did not reveal any changes in NSBHR before and after the test, either to methacholine or mannitol inhalation.

\section{DISCUSSION}

The monitoring of SICTs for the diagnosis of OA in bakers' allergy includes $\mathrm{FEV}_{1}$ changes and the measurement of NSBHR. According to Vandenplas et al., any validated test to detect NSBHR can be used in SICT monitoring [1]. Thus, in this study, the authors have presented a comparison of the measurements of methacholine and mannitol inhalation challenge tests before and after SICTs involving occupational allergens.

The clinical usefulness of methacholine and mannitol tests has been reviewed in a number of studies. Published papers indicate that the mannitol test is reported to have a sensitivity of 55-59\% and a specificity of 73-98\%, while the sensitivity and specificity of the methacholine test is $51-69 \%$ and $75-80 \%$, respectively [6,7]. Some reports have shown that the diagnostic properties of both challenge tests are comparable, and there is a strong agreement between the mannitol and methacholine challenge 
Table 1. Characteristics of the study group consisting of 4 bakery workers with a suspicion of occupational asthma, who were admitted to the Department of Occupational Diseases, Łódź, Poland, in 2015-2016

\begin{tabular}{|c|c|c|c|c|}
\hline \multirow[t]{2}{*}{ Variable } & \multicolumn{4}{|c|}{$\begin{array}{c}\text { Participants } \\
(\mathrm{N}=4)\end{array}$} \\
\hline & case 1 & case 2 & case 3 & case 4 \\
\hline Sex & male & female & male & female \\
\hline Age & 41 years & 32 years & 53 years & 48 years \\
\hline Smoking status & never & never & ex-smoker & ex-smoker \\
\hline Family history of atopy & yes & no & yes & no \\
\hline Animal at home & yes (dog, cat) & no & yes (dog, cat) & yes $(\operatorname{dog})$ \\
\hline Reported symptoms & $\begin{array}{l}\text { eye symptoms, } \\
\text { nasal symptoms, } \\
\text { dysponea }\end{array}$ & $\begin{array}{l}\text { eye symptoms, } \\
\text { nasal symptoms, } \\
\text { cough, dysponea }\end{array}$ & $\begin{array}{l}\text { cough, } \\
\text { dysponea }\end{array}$ & $\begin{array}{l}\text { cough, } \\
\text { dysponea }\end{array}$ \\
\hline \multicolumn{5}{|l|}{ Exposure } \\
\hline occupational exposure time & 20 years & 11 years & 33 years & 27 years \\
\hline symptoms duration at work & 4 years & 6 years & 10 years & 4 years \\
\hline last exposure & working and exposed & working and exposed & 2 years ago & 1.5 years ago \\
\hline
\end{tabular}

test despite the fact that they detect different components of airway hyper-responsiveness [6,7]. Probably, in order to confirm the diagnosis of asthma, performing both the direct and indirect challenge tests may be needed if 1 test is negative, but the pre-test probability of asthma is high.

In this study, the subjects had no strongly positive immunological sensitization. However, SICTs caused a positive response at a relatively high rate. In 3 subjects with positive SICT results, the airway responsiveness to methacholine as a direct stimulus was increased significantly after the challenge tests, while the responsiveness to indirect stimuli was increased significantly in 2 subjects after SICTs.

Few published studies apply to atopic asthmatic patients. For example, Amakye et al. reported that $3 \mathrm{~h}$ after the allergen challenge test, the airway responsiveness to methacholine was increased but, at the same time, the airways became refractory to mannitol challenge [8]. In a study by Davis et al., allergen challenge increased NSBHR to methacholine after $24 \mathrm{~h}$, with a significant increase in the fractional exhaled nitric oxide (FeNO) levels, but decreased NSBHR to mannitol with a non-significant increase in FeNO. This implies that the unexpected nonresponsiveness using mannitol after the allergen challenge test requires further investigation [9].

To the best of the authors' knowledge, the presented study is the first to evaluate airway responsiveness using mannitol before and after SICTs in bakers with work-related airway symptoms although some limitations of this project should be recognized. The main limitation is the size of the study group. The authors examined only 4 subjects, this number being too small to make any statistical comparisons or to draw any significant conclusions. The obtained data should, therefore, be considered only as preliminary results. Moreover, sputum induction was unsuccessful, which happens in $25 \%$ of asthmatic patients [1]. The relationship between allergen-induced airway eosinophilia and airway responsiveness is well documented [10]; however, it could not be shown in this study. Also, due to technical problems, the level of fractional exhaled ni- 
Table 2. The results of skin prick tests (SPTs) to common and occupational allergens, serum allergen-specific IgE antibodies (asIgE) to occupational allergens, and the results of methacholine concentrations and mannitol doses before and after the specific inhalation challenge test (SICT) - performed among 4 bakery workers with a suspicion of occupational asthma, who were admitted to the Department of Occupational Diseases, Łódź, Poland, in 2015-2016

\begin{tabular}{|c|c|c|c|c|}
\hline \multirow{2}{*}{ Test } & \multicolumn{4}{|c|}{ Test results } \\
\hline & case 1 & case 2 & case 3 & case 4 \\
\hline \multicolumn{5}{|l|}{ SPTs to common and occupational allergens } \\
\hline common allergens & negative & positive & negative & negative \\
\hline occupational allergens & positive & positive & positive & positive \\
\hline \multicolumn{5}{|l|}{ asIgE to occupational allergens } \\
\hline fx20 (wheat, rye, barley, rice) & positive & negative & negative & negative \\
\hline fx3 (wheat, oat, maize, sesame seed, buckwheat) & negative & positive & negative & negative \\
\hline $\mathrm{f} 4$ (wheat) $\left[\mathrm{kU}_{\mathrm{A}} / \mathrm{l}\right]$ & 0.46 & 0.25 & 0.25 & 0.14 \\
\hline f5 (rye) $\left[\mathrm{kU}_{\mathrm{A}} / \mathrm{l}\right]$ & 0.61 & 0.35 & 0.23 & 0.10 \\
\hline f6 (barley) $\left[\mathrm{kU}_{\mathrm{A}} / \mathrm{l}\right]$ & 0.23 & 0.19 & 0.21 & 0.09 \\
\hline f7 (oat) $\left[\mathrm{kU}_{\mathrm{A}} \mathrm{ll}\right]$ & 0.18 & 1.39 & 0.15 & 0.03 \\
\hline k87 ( $\alpha$-amylase $)$ & negative & negative & negative & negative \\
\hline \multicolumn{5}{|l|}{ Methacholine challenge test $\left(\mathrm{PC}_{20}[\mathrm{mg} / \mathrm{ml}]\right)$} \\
\hline before SICT & 1.25 & 12.31 & $>16$ & 9.14 \\
\hline after SICT & 0.109 & 1.9 & 1.37 & 5.3 \\
\hline \multicolumn{5}{|l|}{ Dry powder mannitol challenge test $\left(\mathrm{PD}_{15}[\mathrm{mg}]\right)$} \\
\hline before SICT & 78 & 122 & $>635$ & $>635$ \\
\hline after SICT & 6 & 90 & 533 & 509 \\
\hline SICT & $\begin{array}{c}\text { positive } \\
\text { (early response) }\end{array}$ & $\begin{array}{c}\text { positive } \\
\text { (dual reaction) }\end{array}$ & $\begin{array}{c}\text { positive } \\
\text { (early response) }\end{array}$ & negative \\
\hline
\end{tabular}

asIgE - allergen-specific IgE antibody; fx20 (wheat, rye, barley, rice) - allergen-specific IgE antibody to wheat, rye, barley, rice; fx3 (wheat, oat, maize, sesame seed, buckwheat) - allergen-specific IgE antibody to wheat, oat, maize, sesame seed, buckwheat; $\mathrm{f4}$ (wheat) - allergen-specific IgE antibody to wheat; f5 (rye) - allergen-specific IgE antibody to rye; f6 (barley) - allergen-specific IgE antibody to barley; f7 (oat) - allergen-specific IgE antibody to oat; $\mathrm{k} 87$ ( $\alpha$-amylase) - allergen-specific IgE antibody to $\alpha$-amylase; $\mathrm{PC}_{20}$ - the provocation concentration of methacholine to cause a $20 \%$ decrease in the forced expiratory volume in $1 \mathrm{~s}\left(\mathrm{FEV}_{1}\right) ; \mathrm{PD}_{15}$ - the provocation dose of mannitol to cause a $15 \%$ decrease in the forced expiratory volume in $1 \mathrm{~s}\left(\mathrm{FEV}_{1}\right)$; SICT - specific inhalation challenge test; SPTs - skin prick tests.

tric oxide was not measured. Both the level of FeNO and eosinophilic count are considered to provide a reasonably good indication of airways inflammation, and indirect challenge tests correlate better with both eosinophilic airways and asthma [10].

\section{CONCLUSIONS}

In summary, the preliminary data presented above show no clear correlation between the tests evaluating NSBHR with methacholine and mannitol. The results obtained by the authors indicate the need for further investigations to evaluate the usefulness of the mannitol challenge test in the monitoring of SICT diagnostics of OA.

\section{REFERENCES}

1. Vandenplas O, Suojalehto H, Cullinan P. Diagnosing occupational asthma. Clin Exp Allergy. 2017;47(1):6-18, https://doi. org/10.1111/cea.12858. 
2. Hewitt DJ. Interpretation of the "positive" methacholine challenge. Am J Ind Med. 2008;51(10):769-81, https://doi. org/10.1002/ajim.20631.

3. De Menezes MB, Ferraz E, Brannan JD, Martinez EZ, Vianna EO. The efficacy and safety of mannitol challenge in a workplace setting for assessing asthma prevalence. J Asthma. 2018;55(12):1278-85, https://doi.org/10.1080/02770903.2 017.1418887.

4. Wiszniewska M, Nowakowska-Świrta E, Pałczyński C, Walusiak-Skorupa J. Diagnosing of bakers' respiratory allergy: Is specific inhalation challenge test essential? Allergy Asthma Proc. 2011;32(2):111-8.

5. Brannan JD, Anderson SD, Perry CP, Freed-Martens R, Lassig AR, Charlton B. The safety and efficacy of inhaled dry powder mannitol as a bronchial provocation test for airway hyperresponsiveness: a phase 3 comparison study with hypertonic (4.5\%) saline. Respir Res. 2005;6:144, https://doi.org/ 10.1186/1465-9921-6-144.

6. Sverrild A, Porsbjerg C, Thomsen SF, Backer V. Airway hyperresponsiveness to mannitol and methacholine and exhaled nitric oxide: A random-sample population. J Allergy Clin Immunol. 2010;126(5):952-8, https://doi.org/1016/j.jaci.2010. 08.028 .

7. Anderson SD, Charlton B, Weiler JM, Nichols S, Spector SL, Pearlman DS. Comparison of mannitol and methacholine to predict exercise-induced bronchoconstriction and a clinical diagnosis of asthma. Respir Res. 2009;10:4, https:// doi.org/10.1186/1465-9921-10-4.

8. Amakye DO, Davis BE, Martin AL, Peters GE, Cockcroft DW. Refractoriness to inhaled mannitol 3 hours after allergen challenge. Ann Allergy Asthma Immunol. 2013;111(3):182-4, https://doi.org/10.1016/j.anai.2013.06.011.

9. Davis BE, Amakye DO, Cockcroft DW. Airway responsiveness to mannitol $24 \mathrm{~h}$ after allergen challenge in atopic asthmatics. Allergy. 2015;70(6):682-8, https://doi.org/10.1111/all.12601.

10. Lemiere C, Miedinger D, Jacob V, Chaboillez S, Tremblay C, Brannan JD. Comparison of methacholine and mannitol bronchial provocation tests in workers with occupational asthma. J Allergy Clin Immunol. 2012;129(2):555-6, https:// doi.org/10.1016/j.jaci.2011.09.012.

This work is available in Open Access model and licensed under a Creative Commons Attribution-NonCommercial 3.0 Poland License - http://creativecommons.org/ licenses/by-nc/3.0/pl/deed.en. 